\title{
The Effects of Elevated Root Zone Temperature on the Development and Carbon Partitioning of Spring Wheat
}

\author{
Oscar Monje ${ }^{1}$, Sylvia Anderson, and Gary W. Stutte \\ Dynamac Corporation, Space Life Sciences Laboratory, Mail Code Dyn-3, Kennedy Space Center, \\ Florida 32899
}

\begin{abstract}
Additional index words. Triticum aestivum, space, threshold response, leaf area, root module
Abstract. The effect of elevated root zone temperature $\left(+0,+4,+6,+8\right.$, and $\left.+11{ }^{\circ} \mathrm{C}\right)$ on growth rates and carbon partitioning of 'USU-Apogee' spring wheat (Triticum aestivum L.) plants growing at constant air temperature $\left(24^{\circ} \mathrm{C}\right)$ in Turface was investigated. This experiment was performed to determine if wheat growth responded to elevated root zone temperature (RZT) and if so, to determine the temperatures for those responses. The RZT treatments were initiated $5 \mathrm{~d}$ after planting (DAP) to prevent RZT effects on germination from affecting results. The effects of increased RZT on development and carbon partitioning were determined from data collected during destructive harvests at $7,15,22$, and 28 DAP. At a constant air temperature of $24{ }^{\circ} \mathrm{C}$, reduced plant height was observed by 15 DAP at $30{ }^{\circ} \mathrm{C} \mathrm{RZT}\left(+6^{\circ} \mathrm{C}\right)$, and reduced leaf area was observed by $22 \mathrm{DAP}$ at $28^{\circ} \mathrm{C} \mathrm{RZT}\left(+4^{\circ} \mathrm{C}\right)$. Changes in leaf photosynthesis and stomatal conductance $\left(g_{S}\right)$ were not observed until $35^{\circ} \mathrm{C} R Z T\left(+11{ }^{\circ} \mathrm{C}\right)$, which was lethal by 22 DAP. Changes in carbon partitioning resulted in decreased leaf mass and increased stem and head mass fractions as well as accelerated development of reproductive structures. Although elevated RZT temperatures above air temperature affected physiological and morphologic parameters, they did not change plant phenology.
\end{abstract}

The challenge of modern agriculture lies in sustaining high production rates while managing biotic and environmental pressures that reduce yield. In nature, environmental pressures are brought about by climatic changes, and in controlled environment production systems, they result from subsystem failures or poor control of key environmental parameters (Monje et al., 2003). Generally, high temperature stress reduces crop yield because it negatively affects several plant physiological processes, including photosynthesis, respiration, growth, development (phenology and morphology), and partitioning (White and Reynolds, 2003). However, quantifying crop responses to temperature has been difficult because different plant organs typically experience different thermal regimes (Monteith and Unsworth, 1990), the observed acclimatization responses vary according to the conditions a plant has been growing in, and the various physiological processes responding to temperature changes can interact to affect overall growth and yield (White and Reynolds, 2003).

It is important to measure temperature in a physiologically meaningful manner when studying plant development. In wheat, air temperature is a primary factor determining the phyllochron (e.g., the rate of leaf appearance) (McMaster et al., 2003), but soil temperature near the crown may better reflect shoot apex temperature than air temperature because the shoot apex of annual grass crops is located in the crown until the developmental stage of jointing (McMaster and Wilhelm, 2003). However, heating the shoot apex at crown depth of spring wheat by $+3{ }^{\circ} \mathrm{C}$ does not speed up phenologic develop-

Received for publication 27 Mar. 2006. Accepted for publication 24 Jan. 2007. This research was supported though a grant from NASA's Office of Biological and Physical Research Programs (NNK04EB08A) and the Life Sciences Service Contract (NAS10-02001) at NASA's Kennedy Space Center.

${ }^{1}$ Corresponding author. E-mail: oscar.a.monje@nasa.gov. ment or leaf appearance rates probably because leaf growth may occur above the soil surface (McMaster et al., 2003).

Several studies have examined root zone temperature (RZT) effects in lettuce (Lactuca sativa L.) (He et al., 2001), wheat (Guedira and Paulsen, 2002; Kirkham and Ahring, 1978), and creeping bentgrass (Agrostis stolonifera L.) (Rachmilevitch et al., 2006; Xu and Huang, 2000). Root zone temperature can alter shoot growth responses by influencing the temperature of the shoot apical meristem (McMaster et al., 2003), modifying hormonal balance (Tachibana et al., 1997; Wang et al., 2004), and altering water and nutrient uptake (Bowen, 1991). Although the most important factors responsible for reduced yield of wheat at high temperature are the reduction in the length of the growth cycle and the duration of grain fill (White and Reynolds, 2003), RZT has been reported to influence the response of plant growth rates to high air temperature.

Increasing RZT from 12 to $25^{\circ} \mathrm{C}$ generally improves root functions related to supplying water and nutrients to shoots, leading to decreased root-to-shoot ratios, improved gas exchange, and increased chlorophyll content (Awal et al., 2003). Increasing RZT from 25 to $30{ }^{\circ} \mathrm{C}$ increases root-toshoot ratios (Awal et al., 2003) and can increase photosynthetic rates (Ziska, 1998). However, further increases in RZT can lead to growth inhibition by reducing nutrient uptake and chlorophyll content (Du and Tachibana, 1994), disturbing plant water relations and reducing $g_{\mathrm{S}}$ (Behboudian et al., 1994) or altering plant chemical signaling (Dodd et al., 2000; Tachibana et al., 1997; Wang et al., 2004).

Elevated RZT in the heat shock range $\left(\approx 35^{\circ} \mathrm{C}\right)$ appears to be more critical than air temperature in controlling plant growth. Earlier leaf senescence was observed in wheat exposed to $35^{\circ} \mathrm{C}$ RZT and a 16-h photoperiod (Kuroyanagi and Paulsen, 1988). Tomato (Solanum lycopersicum L.) plants growing at $36{ }^{\circ} \mathrm{C}$ RZT for $20 \mathrm{~d}$ exhibited decreased shoot growth and P uptake compared with plants growing at $25{ }^{\circ} \mathrm{C}$ RZT (Klock et al., 
1997). The probable causes for growth reductions at high RZT $\left(37^{\circ} \mathrm{C}\right)$ are increased respiratory costs for maintenance and ion uptake (Rachmilevitch et al., 2006).

Kirkham and Ahring (1978) studied the effect of RZT on leaf temperature and internal water status of wheat at a constant air temperature $\left(25^{\circ} \mathrm{C}\right)$ and ambient $\mathrm{CO}_{2}$ concentration $\left(380 \mu \mathrm{mol} \cdot \mathrm{mol}^{-1}\right)$. Plant height and $g_{\mathrm{S}}$ were greatest when air and root temperatures were similar, but plant height, water potential, and $g_{S}$ decreased when RZT exceeded air temperature. Guedira and Paulsen (2002) reported that applying differential shoot and root temperatures to maturing wheat plants affected kernel mass. Increasing shoot temperature to $30{ }^{\circ} \mathrm{C}$ and keeping the roots at $15{ }^{\circ} \mathrm{C}$ decreased kernel mass by $40 \%$, whereas holding the shoots at $15^{\circ} \mathrm{C}$ and increasing the roots to $30{ }^{\circ} \mathrm{C}$ decreased kernel mass by $57 \%$ compared with maintaining the whole plant at $15^{\circ} \mathrm{C}$. The greater reduction in kernel mass from higher root temperature than from high shoot temperature suggests that roots may regulate partitioning during grain filling. In another RZT study conducted with vegetative winter wheat grown in elevated $\mathrm{CO}_{2}$, the developmental stage of the crop determined the severity of damage experienced by the plant. Increases in RZT and $\mathrm{N}$ supply reduced allocation to roots and leaves and increased allocation to the stem, although an effect on carbon assimilation rate was not observed (Gavito et al., 2001). Furthermore, RZT affected mainly nutrient uptake and plant size during vegetative growth and its effects on root and shoot phenology became evident toward the end of vegetative growth.

This study was conducted in preparation for the Photosynthesis Experiment Subsystem Testing and Operation (PESTO) spaceflight experiment. PESTO examined the effects of microgravity on photosynthetic and growth rates using 21 -d-old crop stands of 'USU-Apogee' wheat (Monje et al., 2005; Stutte et al., 2005). 'USU-Apogee' was grown aboard the International Space Station (ISS) in the Biomass Production System [BPS (Orbitec, Madison, Wis.)]. The BPS consists of four automated plant growth chambers providing active control of air temperature, relative humidity, $\mathrm{CO}_{2}$ concentration, root zone moisture, and light level during spaceflight. Like in most spaceflight plant growth chambers, RZT was not controlled because of power limitations to the BPS imposed by the ISS (Morrow and Crabb, 2000). Although gravity does not change RZT directly, the lack of gravity in space reduces buoyancy-driven heat transfer, and even well-ventilated hardware (e.g., root modules) is expected to be hotter than on earth (Monje et al., 2003). Therefore, the effects of elevated RZT on the vegetative growth of 'USU-Apogee' were studied to determine if increased RZT might confound growth responses observed in PESTO. The objectives were to determine the RZTs at which plant growth and carbon partitioning are affected as well as determine which physiological and morphologic responses might occur when these RZTs are exceeded.

\section{Materials and Methods}

Cultural conditions. 'USU-Apogee' spring wheat was chosen for the PESTO experiment because it is a high-yielding semidwarf cultivar (40 cm tall) suited for growth in controlled environments (Bugbee and Koerner, 1997). 'USU-Apogee' reaches the booting stage by $20 \mathrm{~d}$ after planting (DAP) and anthesis by 33 DAP (Monje and Bugbee, 1998). This is 7 to $8 \mathrm{~d}$ faster than that of field-grown wheat reported by McMaster et al. (2005), but the 12- to 13-d duration between the booting and anthesis stages is the same as in the field. The experiments were conducted in $264-\mathrm{cm}^{2}(18.2 \mathrm{~cm} \times 14.5 \mathrm{~cm})$ by 3 -cm-deep root modules. Each root module was packed with $\approx 500 \mathrm{~g}$ of Turface (calcined montmorillonite clay sifted to 1 to $2 \mathrm{~mm}$; Profile Products, Buffalo Grove, Ill.) mixed with Osmocote (The Scotts Company, Marysville, Ohio) slow-release fertilizer at $7 \mathrm{~g} \cdot \mathrm{L}^{-1}$ or $12 \mathrm{~g} \cdot \mathrm{kg}^{-1}$ of substrate. The root modules contained 32 wheat plants seeded in four rows at a planting density of 1200 plants $/ \mathrm{m}^{2}$ (Stutte et al., 2000). The root modules were watered by a static head moisture controller. Wheat was grown in four root modules in a walk-in growth chamber (model M-48; Environmental Growth Chambers, Chagrin Falls, Ohio) that provided light (cool white fluorescent lamps; $300 \mu \mathrm{mol} \cdot \mathrm{m}^{-2} \cdot \mathrm{s}^{-1}$ ), a $16-\mathrm{h}$ photoperiod, $\mathrm{CO}_{2}$ concentration $\left(1500 \mu \mathrm{mol} \cdot \mathrm{mol}^{-1}\right)$, relative humidity $(75 \%)$, and air temperature $\left(24{ }^{\circ} \mathrm{C}\right.$ day/night $)$ control. RZT treatments were imposed at 5 DAP after the seedlings had germinated.

Static head root zone Moisture controller. The root modules were watered by a recirculating standpipe system. The root modules were filled with water on planting, which moistened the seeds, and then were connected to the standpipe system. Plants were grown at a matric potential of $-0.3 \mathrm{kPa}$ measured by a calibrated differential pressure sensor (model MPX2010D; Motorola, Schaumburg, Ill.) located at mid-root module height (Morrow and Crabb, 2000). This moisture setpoint $(-0.3 \mathrm{kPa})$ was previously found to produce optimum growth of wheat in these root modules (Monje et al., 2001). In that study, plants grown at $-0.1 \mathrm{kPa}$ were stunted as a result of waterlogging and those grown at $-0.5 \mathrm{kPa}$ were stunted as a result of insufficient water.

ROOT ZONE TEMPERATURE EXPERIMENTS. A replicated, 28-dlong experiment consisting of growing vegetative wheat crops in elevated RZTs $\left[+0^{\circ} \mathrm{C}\left(24^{\circ} \mathrm{C}\right),+4^{\circ} \mathrm{C}\left(28^{\circ} \mathrm{C}\right),+6{ }^{\circ} \mathrm{C}\left(30^{\circ} \mathrm{C}\right)\right.$, $+8{ }^{\circ} \mathrm{C}\left(32{ }^{\circ} \mathrm{C}\right)$, and $\left.+11{ }^{\circ} \mathrm{C}\left(35^{\circ} \mathrm{C}\right)\right]$, while keeping air temperature constant $\left(24{ }^{\circ} \mathrm{C}\right)$, was conducted. The PESTO experiment used 21-d-old plants, but here the experiment was extended to 28 DAP to allow changes in partitioning in response to RZT to be observed. A control of $24{ }^{\circ} \mathrm{C}$ RZT was used because RZT during the PESTO ground tests equaled the $24{ }^{\circ} \mathrm{C}$ air temperature.

Each replicate growth cycle was conducted in four root modules within the walk-in growth chamber. RZT in three of the root modules was increased during the photoperiod and maintained at the desired setpoint $\pm 0.5{ }^{\circ} \mathrm{C}$ using computercontrolled heaters. A fourth root module was allowed to equilibrate with air $\left(24{ }^{\circ} \mathrm{C}\right)$ temperature within the growth chamber and used as the ambient control. A datalogger (model CR-10; Campbell Scientific, Logan, Utah) used root temperature measured by a thermocouple placed at mid-root module height $(1.5 \mathrm{~cm})$ to activate the $15.2-\mathrm{cm}$ diameter silicone rubber heaters (model HR555R7.4L12B; Minco, Minneapolis, Minn.) placed under each root module when RZT fell below the desired setpoint. The RZT treatments were imposed from 5 DAP until 28 DAP. The $+11^{\circ} \mathrm{C}\left(35^{\circ} \mathrm{C}\right)$ root zone temperature treatment during the first growth cycle proved to be lethal to wheat after $17 \mathrm{~d}$ (22 DAP); thus, the second repetition of that treatment was conducted during the second growth cycle at $+8{ }^{\circ} \mathrm{C}\left(32{ }^{\circ} \mathrm{C}\right)$ instead.

Plant growth measurements. Time-course harvests for growth analysis were performed at $7,15,22$, and 28 DAP in each growth cycle. Four plants per root module were removed 
at each harvest. Harvesting consisted of cutting the shoot from the root module at crown height. Root biomass per plant was not measured because it was impossible to remove and disentangle the roots from the root module after 5 DAP. Plant height, leaf area, and dry weight of leaves and stems were measured at each harvest date. The immature heads were dissected by unrolling the stem sheaths at 28 DAP. The length and dry weight of the developing wheat spikes were measured. Leaf, stem, and head mass fractions were calculated from the ratio of the organ mass to total dry weight at 28 DAP. The Haun stage of the wheat plants was recorded at 15 DAP to determine if leaf appearance rates were affected by changes in RZT. The dates at which specific developmental stages (i.e., double ridge and internode elongation) occur in 'USU-Apogee' were calculated using the air temperature used in this study and the thermal time of each stage (e.g., growing degree-days) for spring wheat (McMaster et al., 2005). Leaf width was measured at half leaf length. Leaf area was measured with a leaf area meter (model 3100; LI-COR, Lincoln, Nebr.). Plant tissues were oven-dried at $70{ }^{\circ} \mathrm{C}$ for $72 \mathrm{~h}$ to determine dry weight.

Leaf LeVEl Measurements. Photosynthesis and $g_{S}$ on attached 15-d-old leaves were measured during the first growth cycle using a LI-COR 6400 Portable Photosynthesis System to determine if RZT affects leaf photosynthetic rates or transpiration through changes in $g_{\mathrm{S}}$. Gas exchange from the middle portion of randomly selected flag leaves was measured at 15 DAP. A- $\mathrm{C}_{i}\left(\mathrm{~A}=\right.$ photosynthesis rate, $\mathrm{C}_{i}=$ concentration of $\mathrm{CO}_{2}$ inside the leaf) and stomatal response curves to $\mathrm{CO}_{2}$ concentration were obtained by holding the light level in the LI-COR leaf chamber constant. Two measurements per temperature treatment $\left(24,28,30,35^{\circ} \mathrm{C}\right)$ were made at $\mathrm{CO}_{2}$ levels of 75 , $150,300,600$, and $800 \mu \mathrm{mol} \cdot \mathrm{mol}^{-1}$. Gas exchange rates were not measured at $1500 \mu \mathrm{mol} \cdot \mathrm{mol}^{-1}$ to shorten the time for sampling. The responses of net assimilation rate and $g_{\mathrm{S}}$ to $\mathrm{CO}_{2}$ concentration saturate at $1000 \mu \mathrm{mol} \cdot \mathrm{mol}^{-1}$ and are not significantly different from rates measured at $800 \mu \mathrm{mol} \cdot \mathrm{mol}^{-1}$ (data not shown). The LI-COR leaf chamber environment was maintained at a saturating light level of $1000 \mu \mathrm{mol} \cdot \mathrm{m}^{-2} \cdot \mathrm{s}^{-1}$, relative humidity of $75 \%$, and $24{ }^{\circ} \mathrm{C}$. Light was provided by a $\mathrm{red} / \mathrm{blue}$ light-emitting diode light source. The $\mathrm{A}-C_{i}$ curves measure photosynthetic capacity because changes in the activity of the carboxylation enzyme (Rubisco) and in the maximum rate of electron transport used for Rubisco bis-phosphate (RuBP) regeneration can be detected (Long and Bernacchi, 2003).

EXPERIMENTAL DESIGN. Five levels of RZT were tested in four root modules during two growth cycles. The temperature assignment for each root module was not changed from one complete plant growth cycle to the next except to reuse one or more root modules for the fifth root zone temperature. Therefore, RZT effects are confounded with root module effects; however, there were no root module effects in the analysis of a previous experiment using the same root modules (Monje et al., 2005). Observations were made on multiple plants from each root module for each growth cycle, and each plant was treated as an independent observation. The $+0{ }^{\circ} \mathrm{C}\left(24{ }^{\circ} \mathrm{C}\right),+4{ }^{\circ} \mathrm{C}$ $\left(28^{\circ} \mathrm{C}\right)$, and $+6{ }^{\circ} \mathrm{C}\left(30^{\circ} \mathrm{C}\right)$ temperature treatments were repeated twice (two growth cycles) and the $+8{ }^{\circ} \mathrm{C}\left(32^{\circ} \mathrm{C}\right)$ and $+11{ }^{\circ} \mathrm{C}\left(35^{\circ} \mathrm{C}\right)$ treatments only once (one growth cycle). An effects analysis was conducted using a one-way analysis of variance with unequal numbers of observations per treatment using root temperature as a classification variable (PROC GLM; SAS Institute, Cary, N.C.). Normal probability plots of the residuals were examined to ensure heterogeneity of variance. The differences in least squares means for each level were used to determine growth differences between treatments.

\section{Results}

Growth at elevated RZT did not alter the leaf appearance rates because all plants from all treatments reached the same Haun stage of 3.5 by 15 DAP. A $+4{ }^{\circ} \mathrm{C}\left(28^{\circ} \mathrm{C}\right.$ RZT $)$ increase in RZT above-air temperature (Fig. 1) did not affect plant height until after 15 DAP (or $10 \mathrm{~d}$ after the RZT treatments began). Significant differences in plant height were evident by 15 DAP for RZTs greater than $+6{ }^{\circ} \mathrm{C}\left(30^{\circ} \mathrm{C}\right.$ RZT $)$ above air temperature. The plants growing at $35{ }^{\circ} \mathrm{C} \mathrm{RZT}$ were severely stunted and eventually died by 22 DAP. Leaf area was more sensitive to elevated RZT than plant height (Fig. 2). Leaf area was reduced after exposure to $10 \mathrm{~d}$ of RZTs exceeding $+4{ }^{\circ} \mathrm{C}\left(28{ }^{\circ} \mathrm{C}\right.$ RZT $)$ above air temperature and after $2 \mathrm{~d}$ of exposure at the $+11{ }^{\circ} \mathrm{C}$ $\left(35^{\circ} \mathrm{C}\right.$ RZT) treatment. Leaf area expansion had decreased significantly by 22 DAP for RZTs greater than $+4{ }^{\circ} \mathrm{C}$ above the control $\left(24^{\circ} \mathrm{C}\right.$ air temperature and $24{ }^{\circ} \mathrm{C}$ RZT $)$.

Leaf gas exchange in 15-d-old plants, as measured by the $\mathrm{A}-C_{i}$ curves (Fig. 3A) and by the responses of $g_{\mathrm{S}}$ to $\mathrm{CO}_{2}$ concentration (Fig. 3B), was unaffected until $+6{ }^{\circ} \mathrm{C}\left(30{ }^{\circ} \mathrm{C}\right.$ RZT) was exceeded. A slight increase in $g_{S}$ was observed in the $+4{ }^{\circ} \mathrm{C}$ and $+6{ }^{\circ} \mathrm{C}$ plants compared with the control, but it was not statistically significant. Leaf gas exchange rates were severely reduced by the $+11^{\circ} \mathrm{C}\left(35^{\circ} \mathrm{C}\right.$ RZT $)$ treatment; net photosynthesis fell below the $\mathrm{CO}_{2}$ compensation point and the stomata were practically closed.

Plant dry weight at 28 DAP (Table 1) was not reduced by elevated RZT despite significant decreases in leaf area (Fig. 2). Plant height decreased by $33 \mathrm{~mm}(10 \%)$ at $28^{\circ} \mathrm{C}$ RZT and by another $41 \mathrm{~mm}$ at $32{ }^{\circ} \mathrm{C}(13 \%)$ (Table 1$)$. Leaf width decreased

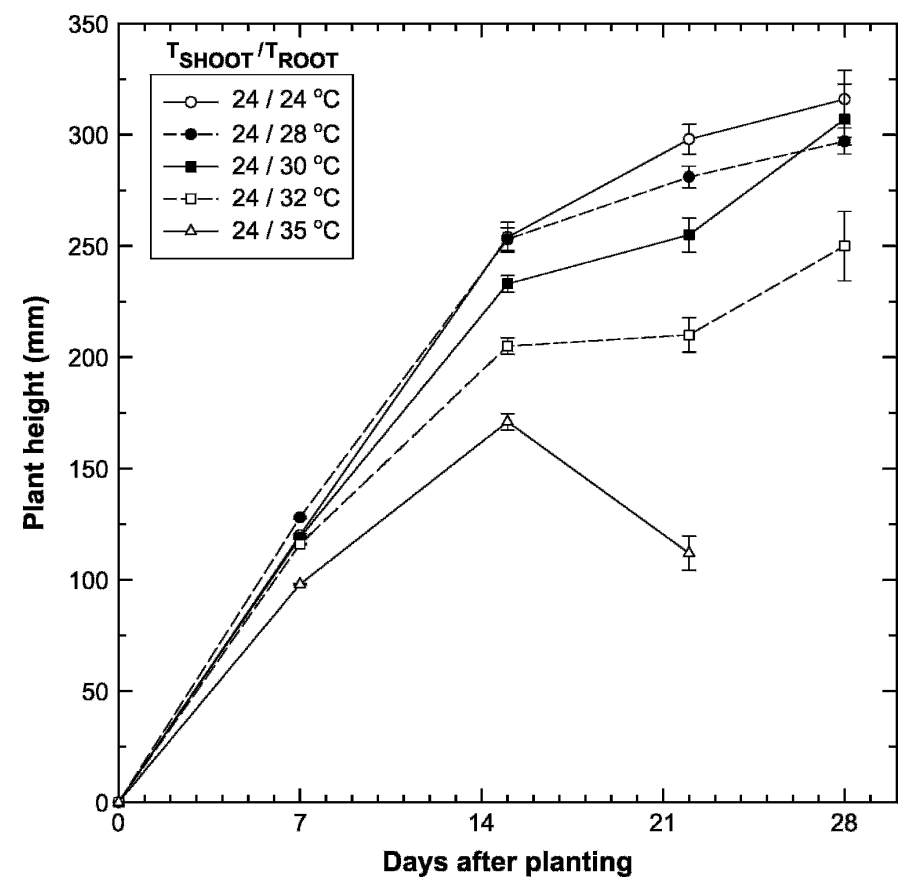

Fig. 1. Effects of shoot $\left(\mathrm{T}_{\mathrm{SHOOT}}\right)$ and root zone $\left(\mathrm{T}_{\mathrm{ROOT}}\right)$ temperature treatments on plant height during development of wheat. Observations represent means \pm standard error. 


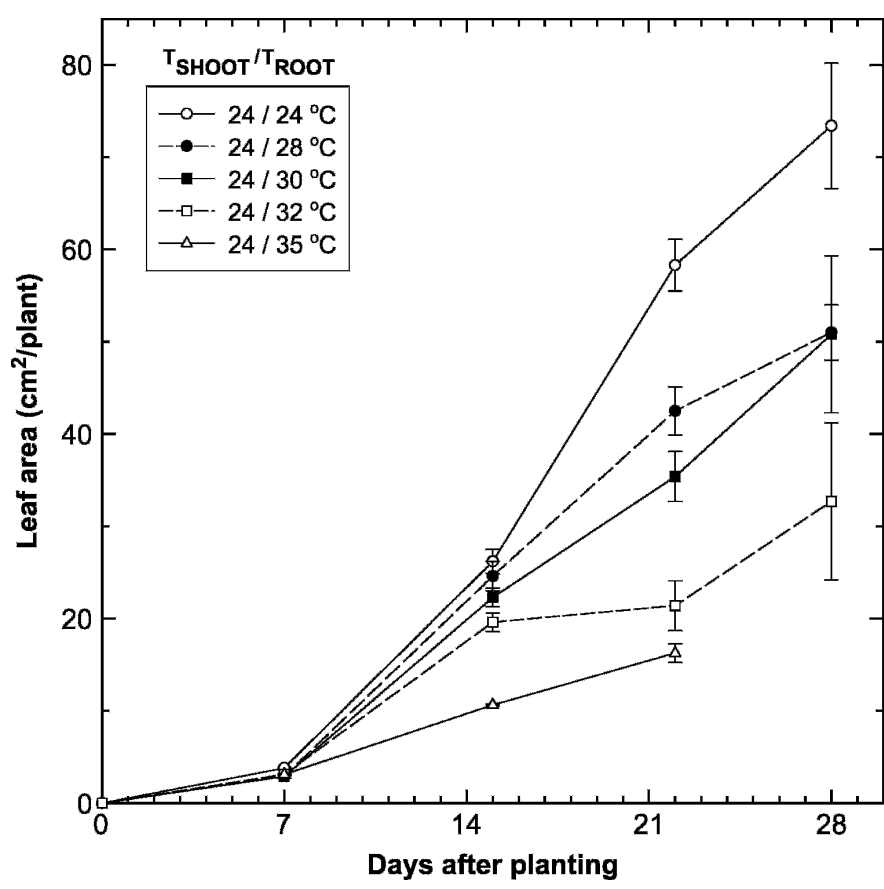

Fig. 2. Effects of shoot $\left(\mathrm{T}_{\mathrm{SHOOT}}\right)$ and root zone $\left(\mathrm{T}_{\text {ROOT }}\right)$ temperature treatments on total leaf area during development of wheat. Observations represent means \pm standard error.

by $2 \mathrm{~mm}(23 \%)$ at $32{ }^{\circ} \mathrm{C}$ RZT compared with the control. Leaf area per plant decreased by $22.4 \mathrm{~cm}^{2}(30 \%)$ at $28{ }^{\circ} \mathrm{C}$ RZT and by another $16.3 \mathrm{~cm}^{2}(22 \%)$ at $32{ }^{\circ} \mathrm{C}$ RZT. In contrast, stem length increased by $37 \mathrm{~mm}(27 \%)$ at $28^{\circ} \mathrm{C} \mathrm{RZT}$ and by another $11 \mathrm{~mm}$ at $32{ }^{\circ} \mathrm{C}(8 \%)$ compared with the control (Table 1$)$.

Elevating RZT above the ambient air temperature also altered the relative fractions of leaf, head, and stem masses after 28 DAP of growth (Fig. 4). The fraction of mass allocated to leaves was $63 \%$ in the $24^{\circ} \mathrm{C}$ RZT control. Increasing RZT at $24{ }^{\circ} \mathrm{C}$ constant air temperature decreased the leaf mass fraction down to $47 \%$ at $28^{\circ} \mathrm{C}$ RZT and down to $19 \%$ at $30{ }^{\circ} \mathrm{C}$ RZT. In contrast, the fraction of mass allocated to stems increased gradually to greater than $50 \%$ at $30{ }^{\circ} \mathrm{C} \mathrm{RZT}$. The head mass fraction rose from $3 \%$ of the $+0{ }^{\circ} \mathrm{C}\left(24{ }^{\circ} \mathrm{C}\right)$ control to $10 \%$ at $+4{ }^{\circ} \mathrm{C}\left(28{ }^{\circ} \mathrm{C} \mathrm{RZT}\right)$ and to $29 \%$ at $+6{ }^{\circ} \mathrm{C}\left(30^{\circ} \mathrm{C}\right.$ RZT) (Fig. $\left.4 \mathrm{~B}\right)$. The increased mass allocation to wheat heads in response to increasing RZTs was also accompanied by a lengthening of the entire wheat spike, indicating that increased RZT probably affected the development of the shoot apex as well. The length of the wheat spike at 28 DAP was 1.5 and 3.1 times longer in the $+4{ }^{\circ} \mathrm{C}\left(28{ }^{\circ} \mathrm{C}\right.$ RZT $)$ and $+6{ }^{\circ} \mathrm{C}\left(30{ }^{\circ} \mathrm{C}\right.$ RZT $)$ treatments, respectively, when compared with $+0{ }^{\circ} \mathrm{C}\left(24{ }^{\circ} \mathrm{C}\right.$ RZT $)$ control.

\section{Discussion}

This work was part of ground studies conducted in preparation for the PESTO flight experiment. PESTO measured vegetative plant stand photosynthetic and transpiration rates of 'USU-Apogee' wheat in microgravity compared with $1 g$ (Monje et al., 2005; Stutte et al., 2005). Because reduced heat transfer in space is expected to result in higher RZTs in plantbased spaceflight experiments (Monje et al., 2003), it was necessary to identify any responses to elevated RZTs (e.g., with respect to air temperature) that could confound growth
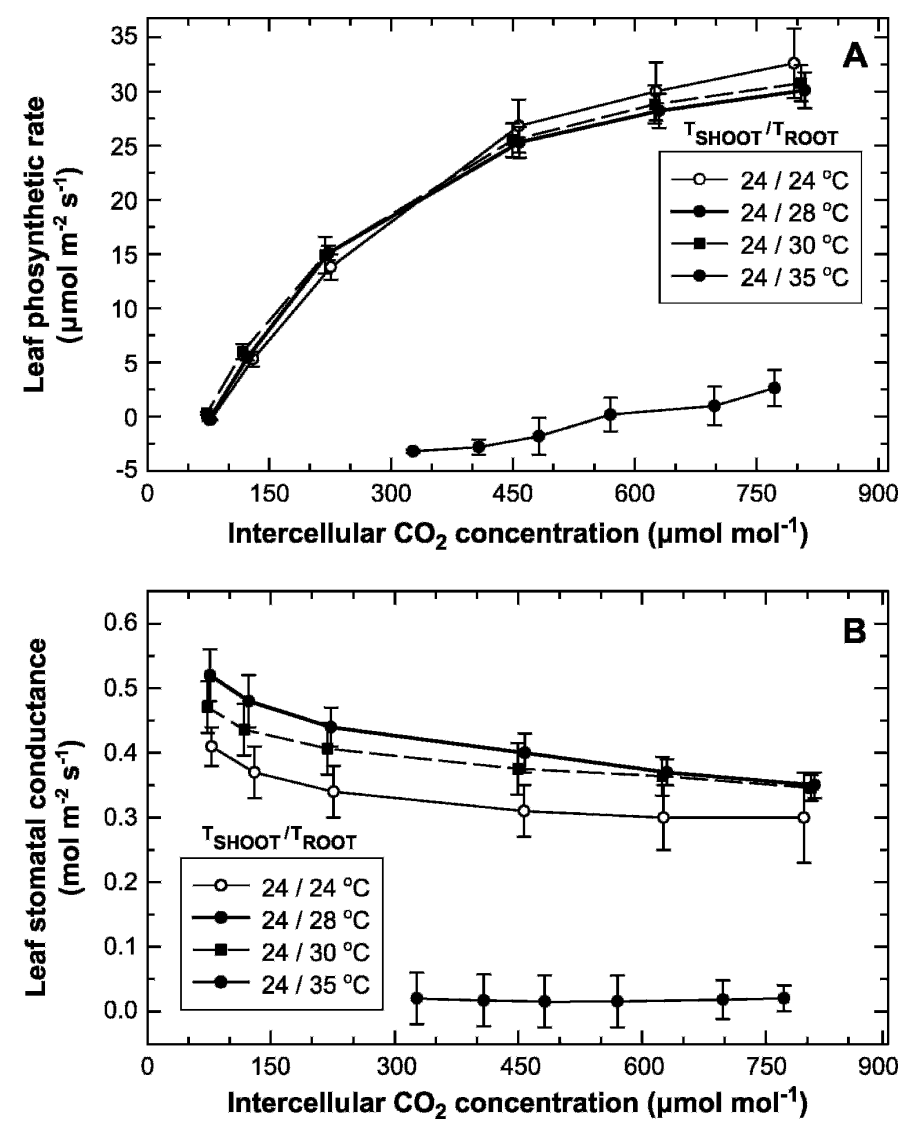

Fig. 3. Effects of shoot $\left(\mathrm{T}_{\text {SHOOT }}\right)$ and root zone $\left(\mathrm{T}_{\text {ROOT }}\right)$ temperature treatments on leaf photosynthetic rates and $g_{\mathrm{S}}$ on 15-d-old wheat plants. No effects of elevated root zone temperature on physiological processes were observed for either (A) leaf photosynthesis; A vs. intercellular $\mathrm{CO}_{2}$ concentration $\left(\mathrm{C}_{i}\right)$ or (B) leaf $g_{\mathrm{S}}$ vs. $\mathrm{C}_{i}$ until the treatment with $+11{ }^{\circ} \mathrm{C}\left(35^{\circ} \mathrm{C} \mathrm{T}_{\text {ROOT }}\right)$ above air temperature. Observations represent means \pm standard error.

responses of wheat to microgravity observed during PESTO. The primary goal of this study was to determine the RZTs at which plant growth is affected and to determine which physiological and morphologic responses might occur when these RZTs are exceeded. Therefore, leaf physiological (e.g., photosynthesis and $g_{\mathrm{S}}$ ) and morphologic measures (e.g., plant height, leaf area, leaf width, and so on) of vegetative wheat plants were examined to determine if growth and carbon partitioning may be altered by continuous exposure to RZTs $\left(+0,+4,+6,+8\right.$, and $\left.+11^{\circ} \mathrm{C}\right)$ higher than a constant air temperature of $24^{\circ} \mathrm{C}$.

Table 1. Effects of root zone temperature on morphologic indices of 28-d-old wheat plants.

\begin{tabular}{lccccc}
\hline $\begin{array}{l}\text { Root zone } \\
\text { temp }\left({ }^{\circ} \mathrm{C}\right)\end{array}$ & $\begin{array}{c}\text { Plant ht } \\
(\mathrm{cm})\end{array}$ & $\begin{array}{c}\text { Stem length } \\
(\mathrm{cm})\end{array}$ & $\begin{array}{c}\text { Leaf area } \\
\left(\mathrm{cm}^{2}\right)\end{array}$ & $\begin{array}{c}\text { Leaf width } \\
(\mathrm{mm})\end{array}$ & $\begin{array}{c}\text { Plant mass } \\
(\mathrm{g})\end{array}$ \\
\hline 24 & $328 \mathrm{a}^{\mathrm{z}}$ & $134.5 \mathrm{a}$ & $73.4 \mathrm{a}$ & $8.4 \mathrm{a}$ & $0.390 \mathrm{a}$ \\
28 & $295 \mathrm{~b}$ & $171.6 \mathrm{~b}$ & $51.0 \mathrm{~b}$ & $8.4 \mathrm{a}$ & $0.353 \mathrm{a}$ \\
30 & $291 \mathrm{~b}$ & $170.0 \mathrm{~b}$ & $49.0 \mathrm{~b}$ & $7.7 \mathrm{a}$ & $0.342 \mathrm{a}$ \\
32 & $250 \mathrm{c}$ & $181.3 \mathrm{~b}$ & $32.7 \mathrm{c}$ & $6.5 \mathrm{~b}$ & $0.287 \mathrm{a}$ \\
$\mathrm{n}^{\mathrm{y}}$ & 78 & 27 & 27 & 27 & 27
\end{tabular}

${ }^{\mathrm{z}}$ Means within a column followed by the same letter are not significantly different $(P \leq 0.05)$ using least squares means procedures.

${ }^{\mathrm{y}} \mathrm{n}=$ number of observations. 

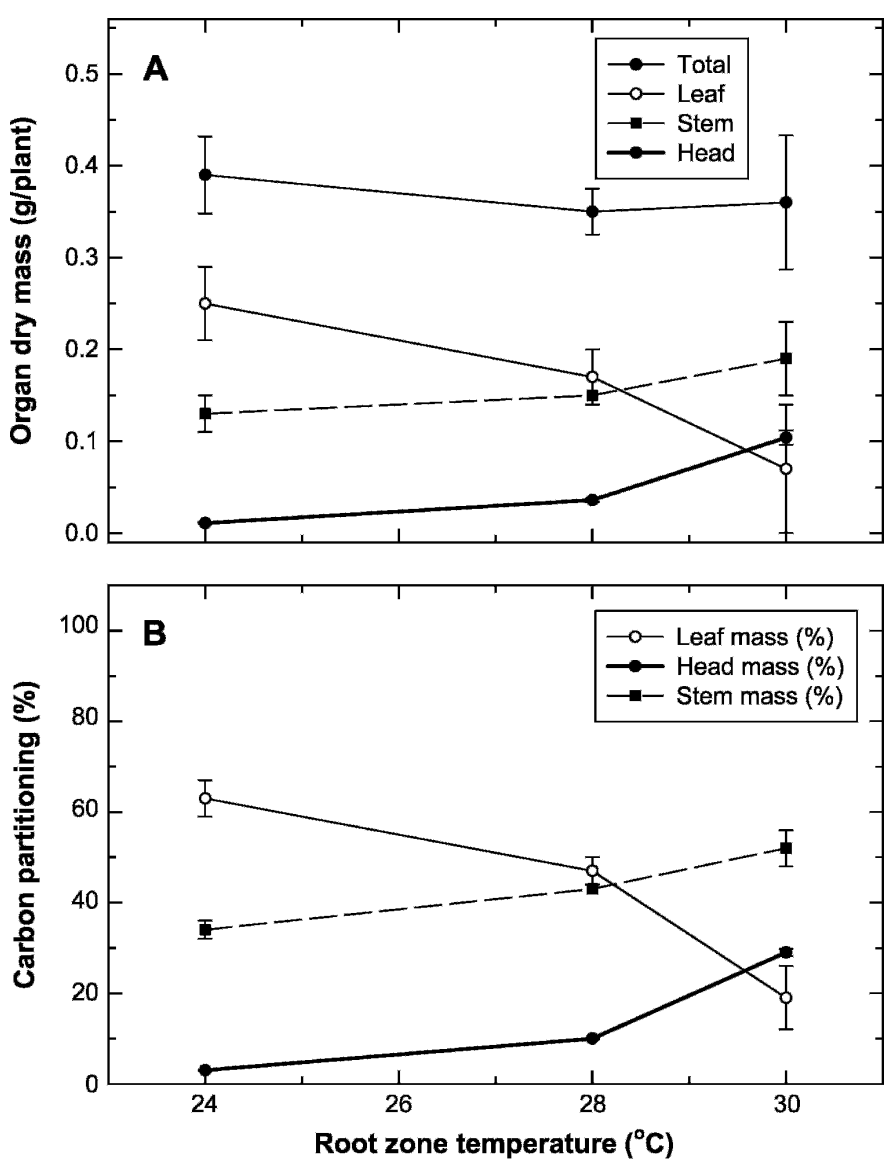

Fig. 4. Effects of root zone temperature (RZT) on (A) organ dry weights and (B) carbon partitioning of 28-d-old wheat plants. Observations represent means \pm standard error.

The root zone treatments were imposed after 5 DAP and leaf appearance rates did not change as plants reached the same Haun stage by 15 DAP at all RZTs. In spring wheat, leaf primordia are initiated soon after the double ridge stage $(\approx 3$ to 5 DAP), and the apex is located in the crown until internode elongation ( $\approx 11$ to 12 DAP) (McMaster et al., 2005). Thus, imposing the elevated RZTs after 5 DAP probably affected only the development of the wheat spike from 5 to 12 DAP while it was still near the crown (e.g., close to the warm root zone) and had no effect on leaf appearance rates because leaf primordia had already developed by then. The observation that elevated RZTs did not increase leaf appearance rates is consistent with results from another elevated RZT study conducted at $+3{ }^{\circ} \mathrm{C}$ above air temperature in field conditions (McMaster et al., 2003).

Morphologic effects were detected after $10 \mathrm{~d}$ of growth at elevated RZTs (15 DAP). In the plants grown at $+6{ }^{\circ} \mathrm{C}\left(30^{\circ} \mathrm{C}\right.$ RZT), plant height (Fig. 1) and leaf area (Fig. 2) were significantly decreased, and increased stem length was observed by 28 DAP (Table 1). Decreased leaf area was observed at $+4{ }^{\circ} \mathrm{C}\left(28^{\circ} \mathrm{C} \mathrm{RZT}\right)$ above air temperature (Fig. 2). Generally, the RZT for reductions in plant height, leaf width, and leaf area was $28^{\circ} \mathrm{C}$ (e.g., $+4{ }^{\circ} \mathrm{C}$ above air temperature).

The effects of elevated RZT on leaf physiological parameters were measured at $15 \mathrm{DAP}$. The $\mathrm{A}-C_{i}$ curves (Fig. $3 \mathrm{~A}$ ) and the responses of $g_{\mathrm{S}}$ to $\mathrm{CO}_{2}$ concentration (Fig. $3 \mathrm{~B}$ ) from plants growing at RZTs up to $+6{ }^{\circ} \mathrm{C}\left(30{ }^{\circ} \mathrm{C}\right.$ RZT $)$ above air temperature were nearly identical. However, growth at +11 ${ }^{\circ} \mathrm{C}\left(35^{\circ} \mathrm{C}\right) \mathrm{RZT}$ inhibited photosynthesis and reduced $g_{\mathrm{S}}$, caused visible shoot injury, and was ultimately lethal by 22 DAP. Although leaf gas exchange processes (e.g., Rubisco activity or electron transport rate) and $g_{\mathrm{S}}$ were unaffected by growth at RZTs up to $+6{ }^{\circ} \mathrm{C}\left(30^{\circ} \mathrm{C}\right.$ RZT $)$ above air temperature (Fig. 3), the drastic reductions in leaf photosynthesis and $g_{\mathrm{S}}$ observed at $+11^{\circ} \mathrm{C}\left(35^{\circ} \mathrm{C}\right.$ RZT $)$ suggests that another mechanism, which closes stomata and increases root respiration, begins to operate near this supraoptimal RZT (Huang and Gao, 2000; Rachmilevitch et al., 2006).

The plants in this study were harvested at 28 DAP (e.g., $5 \mathrm{~d}$ before anthesis in this cultivar) and RZT effects on the duration of grain fill could not be observed. However, plants grown above a RZT of $28{ }^{\circ} \mathrm{C}$ exhibited large changes in carbon partitioning as well as in the development of reproductive structures (Fig. 4). The accelerated maturation of the reproductive structures (e.g., increased head length and mass) indicates that elevated RZT hastened the development of spikelet and floret primordia occurring at the shoot apex without affecting leaf appearance rates. Although increasing RZTs up to +4 to $8{ }^{\circ} \mathrm{C}$ above air temperature contributed to reducing plant height and altering carbon partitioning, a significant reduction in plant dry weight was not observed by 28 DAP (Table 1). Plant dry weight was not reduced, probably because decreased leaf area allowed more light to penetrate deeper into the chambers such that the potential decrease in biomass was not realized as a result of increased light capture (Monje et al., 2005).

The changes in partitioning observed in this study [e.g., shorter plant stature (Fig. 1) and increased stem mass (Fig. 4A)] are similar to those reported for increased harvest index in uniculm wheat cultivars (Richards, 1988). A shorter stature may lead to increased harvest index because assimilate normally allocated for long stem growth is diverted to increasing growth of the ears (Araus et al., 2002). Although the plants in this study responded to elevated RZTs by increasing harvest indices, they had reduced leaf areas (Fig. 2). Thus, less carbon was allocated to leaves and the excess carbon was instead allocated to the stem and to reproductive structures (Fig. 4), which is consistent with the changes in carbon partitioning observed in vegetative winter wheat exposed to increased soil temperature (Gavito et al., 2001).

Results from previous studies suggest that several mechanisms may cause physiological and morphologic changes when RZT is increased at a constant air temperature: 1) increased root respiration turns the roots into a major carbon sink for assimilate; 2) the production of root-mediated signals in wellwatered roots is disrupted causing high temperature stress responses in the shoot; and 3) reduced root function at high temperature disrupts nutrient and water uptake. In a recent study investigating the effects of high RZT in creeping bentgrass cultivars differing in thermal tolerance, increased total root respiration rate and specific respiratory costs for maintenance and ion uptake were observed with increasing soil temperatures (Rachmilevitch et al., 2006). Although they also measured decreases in relative growth rate, cell membrane stability, maximum root length, and nitrate uptake, these physiological changes were detected at a very high soil temperature $\left(37^{\circ} \mathrm{C}\right)$. Altering the production of root-mediated signals in response to increased RZT may also affect shoot growth. Elevated RZT studies with creeping bentgrass suggest 
that reduced leaf area could be ascribed to decreased leaf expansion incited by a reduction of root-derived signals in response to elevated RZTs (Liu et al., 2002). However, reduced leaf area may also result from decreased leaf, water, and turgor potentials as RZT increases (Kirkham and Ahring, 1978). Elevated RZT may also lead to shoot injury through disruptions in the shoot antioxidant systems. Reductions in cytokinin content and antioxidant enzyme activity were observed at lower RZTs $\left(25\right.$ to $27^{\circ} \mathrm{C}$ ) and occurred earlier during the treatment than declines in turf quality, suggesting that these changes contributed to reduced turf quality (Wang et al., 2003). Liu and Huang (2005) found that changes in root cytokinins are the earliest $(\approx 5 \mathrm{~d})$ stress indicator for plant responses to high soil temperature; however, they caution that decreased water, nutrient $(\mathrm{N}, \mathrm{P}$, and $\mathrm{K}$ ), and increased abscisic acid could also contribute to reductions in shoot and root growth for creeping bentgrass exposed to high soil temperatures.

Although root biomass, root respiration, or root-derived signals were not measured in this study, several morphologic changes were observed. Carbon allocation to reproductive organs was increased along with a reduction in percent leaf mass and leaf area in response to increased RZT. Furthermore, no changes in leaf gas exchange were detected until RZT exceeded $35^{\circ} \mathrm{C}\left(+11^{\circ} \mathrm{C}\right.$ above air temperature $)$.

\section{Conclusions}

Wheat plant growth and carbon partitioning was modified by elevating RZTs above a constant air temperature. Generally, elevated RZTs above air temperature by up to +6 to $8^{\circ} \mathrm{C}$ caused shorter stature, reduced leaf area, increased stem height, as well as increased carbon allocation to reproductive structures compared with plants growing at RZTs equal to air temperature. Although morphologic changes were observed when RZT is increased by up to $+6{ }^{\circ} \mathrm{C}$, there were no effects observed on physiological processes like leaf photosynthesis or $g_{\mathrm{S}}$. However, at very high RZTs $\left(+11{ }^{\circ} \mathrm{C}\right.$ above air temperature), photosynthesis and $g_{\mathrm{S}}$ was severely hampered, and the plants died after $16 \mathrm{~d}$.

In the context of PESTO, this study indicates that growth and development of plants in space will be similar to that of plants grown on Earth as long as they are cultivated at similar root zone and air temperatures. Furthermore, because the average RZT was $27.1 \pm 1.0^{\circ} \mathrm{C}$ in $1 \mathrm{~g}$ and $27.9 \pm 0.5^{\circ} \mathrm{C}$ in $0 \mathrm{~g}$ during PESTO (Monje et al., 2005), significant differences in plant morphology and between the $1 \mathrm{~g}$ - and $0 \mathrm{~g}$-grown plants are not expected.

\section{Literature Cited}

Araus, J.L., G.A. Slafer, M.P. Reynolds, and C. Royo. 2002. Plant breeding and drought in $\mathrm{C}_{3}$ cereals: What should we breed for? Ann. Bot. (Lond.) 89:925-940.

Awal, M.A., T. Ikeda, and R. Itoh. 2003. The effect of soil temperature on source-sink economy in peanut (Arachis hypogaea). Environ. Exp. Bot. 50:41-50.

Behboudian, M.H., W.R. Graves, C.S. Walsh, and R.F. Korcak. 1994. Water relations, mineral nutrition, growth and ${ }^{13} \mathrm{C}$ discrimination in two apple cultivars under daily episodes of high root-medium temperature. Plant Soil 162:125-133.

Bowen, G.D. 1991. Soil temperature, root growth, and plant function, p. 309-330. In: Y. Waisel, A. Eshel, and U. Kafkafi (eds.). Plant roots-The hidden half. Marcel Dekker, N.Y.
Bugbee, B. and G. Koerner. 1997. Yield comparisons and unique characteristics of the dwarf wheat cultivar 'USU-Apogee'. Adv. Space Res. 20:1891-1894.

Dodd, I.C., J. He, C.G.N. Turnbull, S.K. Lee, and C. Critchley. 2000. The influence of supra-optimal root-zone temperatures on growth and stomatal conductance in Capsicum annuum L. J. Expt. Bot. 51:239-248

Du, Y.C. and S. Tachibana. 1994. Photosynthesis, photosynthate translocation and metabolism in cucumber roots held at supraoptimal temperature. J. Jpn. Soc. Hort. Sci. 63:401-408.

Gavito, M.E., P.S. Curtis, T.N. Mikelsen, and I. Jakobsen. 2001. Interactive effects of soil temperature, atmospheric $\mathrm{CO}_{2}$ and soil $\mathrm{N}$ on root development, biomass and nutrient uptake of winter wheat during vegetative growth. J. Expt. Bot. 52:1913-1923.

Guedira, M. and G.M. Paulsen. 2002. Accumulation of starch in wheat grain under different shoot/root temperatures during maturation. Funct. Plant Biol. 29:495-503.

He, J., S.K. Lee, and I.C. Dodd. 2001. Limitations to photosynthesis of lettuce grown under tropical conditions: Alleviation by root-zone cooling. J. Expt. Bot. 52:1323-1330.

Huang, B. and H. Gao. 2000. Growth and carbohydrate metabolism of creeping bentgrass cultivars in response to increasing temperatures. Crop Sci. 40:1115-1120.

Kirkham, M.B. and R.M. Ahring. 1978. Leaf temperature and internal water status of wheat grown at different root temperatures. Agron. J. 70:657-662.

Klock, K.A., H.G. Taber, and W.R. Graves. 1997. Root respiration and phosphorous nutrition of tomato plants grown at a $36^{\circ} \mathrm{C}$ root-zone temperature. J. Amer. Soc. Hort. Sci. 122:175-178.

Kuroyanagi, T. and G.M. Paulsen. 1988. Mediation of high-temperature injury by roots and shoots during reproductive growth of wheat. Plant Cell Environ. 11:517-523.

Liu, X. and B. Huang. 2005. Root physiological factors involved in cool-season grass response to high soil temperature. Environ. Exp. Bot. 53:233-245.

Liu, X., B. Huang, and G. Banowetz. 2002. Cytokinin effects in creeping bentgrass responses to heat stress. I. Shoot and root growth. Crop Sci. 42:457-465.

Long, S.P. and C.J. Bernacchi. 2003. Gas exchange measurements, What can you tell us about the underlying limitations to photosynthesis? Procedures and sources of error. J. Expt. Bot. 54:2393-2401.

McMaster, G.S. and W.W. Wilhelm. 2003. Phenological responses of wheat and barley to water and temperature: Improving simulation models. J. Agr. Sci. 141:129-147.

McMaster, G.S., W.W. Wilhelm, and A.B. Frank. 2005. Developmental sequences for simulating crop phenology for water-limiting conditions. Austral. J. Agr. Res. 56:1277-1288.

McMaster, G.S., W.W. Wilhelm, D.B. Palic, J.R. Porter, and P.D. Jamieson. 2003. Spring leaf appearance and temperature: Extending the paradigm? Ann. Bot. (Lond.) 91:697-705.

Monje, O. and B. Bugbee. 1998. Adaptation to high $\mathrm{CO}_{2}$ concentration in an optimal environment: Radiation capture, canopy quantum yield and carbon use efficiency. Plant Cell Environ. 21:315-324.

Monje, O., G.W. Stutte, and D. Chapman. 2005. Microgravity does not alter plant stand gas exchange of wheat at moderate light levels and saturating $\mathrm{CO}_{2}$ concentration. Planta 222:336-345.

Monje, O., G.W. Stutte, G.D. Goins, D.M. Porterfield, and G.E. Bingham. 2003. Farming in Space: Environmental and biophysical concerns. Adv. Space Res. 31:151-167.

Monje, O., G.W. Stutte, H.T. Wang, and C.J. Kelly. 2001. NDS water pressures affect growth rate by changing leaf area, not single leaf photosynthesis. Soc. Automotive Eng. Tech. Paper 2001-01-2277.

Monteith, J.L. and M.H. Unsworth. 1990. Principles of environmental physics. Chapman and Hall, N.Y.

Morrow, R.C. and T.M. Crabb. 2000. Biomass Production System (BPS) plant growth unit. Adv. Space Res. 26:289-298.

Rachmilevitch, S., H. Lambers, and B. Huang. 2006. Root respiratory characteristics associated with plant adaptation to high soil temperature 
for geothermal and turf-type Agrostis species. J. Expt. Bot. 57:623631.

Richards, R.A. 1988. A tiller inhibitor gene in wheat and its effect on plant growth. Austral. J. Agr. Res. 39:749-757.

Stutte, G.W., O. Monje, G.D. Goins, and D.K. Chapman. 2000. Measurement of gas exchange characteristics of developing wheat in the Biomass Production Chamber. Soc. Automotive Eng. Tech. Paper 2000-01-2292.

Stutte, G.W., O. Monje, G.D. Goins, and B.C. Tripathy. 2005. Microgravity effects on thylakoid, single leaf, and whole canopy photosynthesis of dwarf wheat. Planta 223:46-56.

Tachibana, S., Y.C. Du, Y.H. Wang, and F. Kitamura. 1997. Implication of endogenous cytokinins in the growth inhibition of cucumber plants by supraoptimal root-zone temperature. J. Jpn. Soc. Hort. Sci. 66:549-555.

Wang, Z., J. Pote, and B. Huang. 2003. Responses of cytokinins, antioxidant enzymes, and lipid peroxidation in shoots of creeping bentgrass to high root-zone temperatures. J. Amer. Soc. Hort. Sci. 128:648-655.

Wang, Z., Q. Xu, and B. Huang. 2004. Endogenous cytokinin levels and growth responses to extended photoperiods for creeping bentgrass under heat stress. Crop Sci. 44:209-213.

White, J.W. and M.P. Reynolds. 2003. A physiological perspective on modeling temperature response in wheat and maize crops, p. 8-17. In: J.W. White (ed.). Modeling temperature response in wheat and maize: Proc. of a workshop. Intl. Maize and Wheat Improvement Center, El Batan, Mexico, 23-25 Apr. 2001. Natural Resources Group Geographic Information Systems Series 03-01.

$\mathrm{Xu}, \mathrm{Q}$. and B. Huang. 2000. Effects of differential air and soil temperatures on carbohydrate metabolism in creeping bentgrass. Crop Sci. 40:1368-1374.

Ziska, L.H. 1998. The influence of root zone temperature on photosynthetic acclimation to elevated carbon dioxide concentrations. Ann. Bot. (Lond.) 81:717-721. 